\title{
CMAJ 2011 election survey: patient safety
}

$\mathrm{C}$ anada, like many developed nations, has struggled in the last two decades to shoulder the growing financial and emotional burden of messy legal battles over patient compensation for medical mishaps.

But, unlike other countries that have since streamlined or adopted new processes of compensating patients for avoidable adverse events, Canada's overall medical liability system has proven resilient to change (www.cmaj .ca/cgi/doi/10.1503/cmaj.081201).

Under Canada's tort-based system, patients who have suffered harm as a result of medical error have no automatic avenue for obtaining redress and, for the most part, must launch lawsuits and prove a physician's individual "fault" in order to receive compensation.

Many patient safety experts argue the system is unfair, particularly as individuals must bear the cost of litigation against doctors, whose insurance premiums are mostly paid by taxpayers via provincial health ministries (www .cmaj.ca/cgi/doi/10.1503/cmaj.081020).

Lawsuits may "help put the fear of God into hospitals to be a bit more careful" (www.cmaj.ca/cgi/doi/10.1503 /cmaj.081130), but observers argue that fear can be a double-edged sword, encouraging some physicians and hospitals to hide medical misadventures rather than learn from their mistakes.

Others question the efficacy of the system, as only a tiny portion of victims of avoidable adverse events (some reports say $10 \%$ or less) actually file a claim, awards are often inequitable, and the process to obtain them is lengthy and uncertain.

Few patients who take a case to trial are successful, in large part because the move to team-based health care delivery has made it increasingly difficult for claimants to meet the system's onus that they prove fault.

Even patients who do win damages see little of the money awarded because of the high legal and administrative costs of the process. More than $50 \%$ of

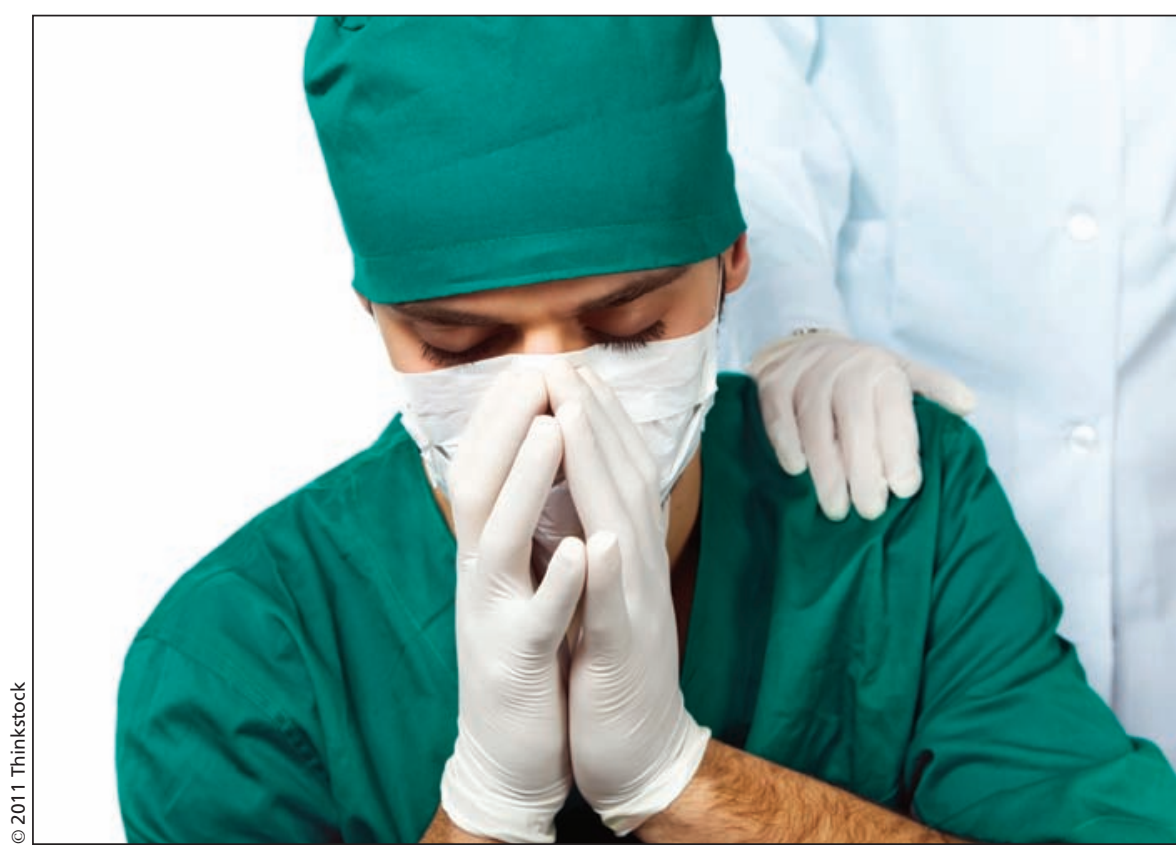

More than $50 \%$ of all money spent on malpractice goes to the expenses of litigation and not to the injured patient for compensation.

all money spent on malpractice goes to the expenses of litigation and not to the injured patient for compensation.

Moreover, by focusing on the misdeeds of individuals rather than the reality that medical errors are often caused by breakdowns in the system as a whole, some argue the process is also needlessly oppositional and emotionally traumatic for patients and health care providers.

Many developed nations, including New Zealand and Denmark, have instituted "no-fault" compensatory regimes in response to these concerns. Under these regimes, patients who experience a certain class of avoidable adverse event are automatically paid by a public fund or through private resources without having to fight for a formal finding of negligence through the courts.

The no-fault compensation plans are also relatively cheaper than tort-based liability systems, and create the conditions for more open exchanges about the circumstances that lead to medical error.

Numerous Canadian reports have called for the creation of a national no- fault compensation scheme to work alongside, rather than replace the courts as a means of redress for patients.

However, the issue has remained all but invisible in Canada, in large part because injured patients lack the lobbying presence to demand change.

Any national scheme would also fall into the jurisdictional no-man's land between federal and provincial-territorial responsibilities, as indicated by some of the federal political parties in CMAJ's 2011 election survey.

The Liberals conceded that the federal government is "well placed to energize a Canadian effort to put quality and safety improvement, best practices and innovation at the forefront," but stopped short of promising federal action on no-fault compensation. Instead, they argued the best way to prevent medical mishaps is to "share best practices among the provinces."

The Bloc Québécois didn't mince as many words, but agreed that such a scheme would fall under the purview of the provinces.

The New Democratic Party deferred 
taking any stance on the issue, saying they would have to "analyse" the proposal first, while the Conservatives declined to answer the survey. - Lauren Vogel, CMAJ

Survey question: Should Canada have no-fault compensation for medical mishaps?

Conservative response:

No response. Rather than participate in CMAJ's 2011 election survey, the Conservatives forwarded a weblink to their party platform. Asked what the rationale was for declining participation, party spokesperson Ryan Sparrow says the weblink constitutes a response to the survey. "That response is the response from the campaign."

Liberal response:

"Medical mishaps are always a tragedy. Liberals believe that one of the key ways to prevent medical mishaps is to share best practices among the provinces.

Provinces are working individually to address concerns about service quality and safety in healthcare delivery. But successful innovations in management and service delivery are too often confined to one location. The work of bodies set up at the national and provincial levels to foster quality improvement in a wide range of specific services has not been fully exploited nationally.

Identifying and adopting the most effective and efficient delivery methods from other jurisdictions - when undertaken broadly and systematically can reduce costs while improving the quality and safety of care.

The federal government is well placed to energize a Canadian effort to put quality and safety improvement, best practices and innovation at the forefront. This has to be a national effort, and a Liberal government will make it a priority again. The federal government has established valuable instruments, including the Canadian Institutes of Health Information, the Canadian Patient Safety Institute, the Canadian Health Services Research Foundation and Canada Health Infoway serving all jurisdictions. These bodies are key to progress. Particularly with respect to health outcomes for Aboriginal people, Ottawa must make quality improvement a top priority."

New Democrat response:

"A New Democrat government would have to analyse any proposal to ensure it is a benefit to Canadians before making a decision."

Bloc Québécois response:

"La santé étant un domaine de compétence qui relève exclusivement du Québec et des provinces, la pratique de la médecine au Québec étant d'ailleurs encadrée par le Collège des médecins du Québec, le Bloc Québécois juge que ces derniers sont les mieux à même de débattre de cette question."

CMAJ 2011. DOI:10.1503/cmaj.109-3882

Editor's note: Last of a series of stories on CMAJ's 2011 election survey:

Part 1: Health transfers (www.cmaj.ca/cgi/doi/10.1503/cmaj.109-3865)

Part 2: Pharmacare (www.cmaj.ca/cgi/doi/10.1503/cmaj.109-3870)

Part 3: Health human resources (www.cmaj.ca/cgi/doi/10.1503/cmaj.109-3875)

Part 4: Home/palliative care (www.cmaj.ca/cgi/doi/10.1503/cmaj.109-3876)

Part 5: Research (www.cmaj.ca/cgi/doi/10.1503/cmaj.109-3877)

Part 6: Food safety (www.cmaj.ca/cgi/doi/10.1503/cmaj.109-3878)

Part 7: Transparency (www.cmaj.ca/cgi/doi/10.1503/cmaj.109-3879)

Part 8: Public health (www.cmaj.ca/cgi/doi/10.1503/cmaj.109-3880)

Part 9: Electronic health records (www.cmaj.ca/cgi/doi/10.1503/cmaj.109-3881) 